\title{
MOSQUITOS COLLECTED IN PALESTINE AND ADJACENT
} TERRITORIES.

\author{
By Capt. P. J. Barraud, F.Z.S., F.E.S.
}

These notes include observations made on the mosquito fauna of Palestine, for the period July 1919 to August 1920.

In September and October 1919 a somewhat rapid tour was made through Syria and Cilicia, while from time to time short visits have been made to Egypt.

The climate of this part of the Mediterranean region is divided into wet and dry seasons, the latter usually prevailing from May to October, inclusive. In the northern parts of Syria and Cilicia the dry season is of rather shorter duration. From November to April there is a heavy rainfall over the larger part of Palestine and the countries to the north, but in the lower Jordan Valley, and in the deserts of the south, the amount is much less. The winter is mild, especially along the coastal belt and in the lower Jordan region, the thermometer seldom falling to freezing point. In some seasons there may, however, be a considerable snowfall in the mountains.

With the advent of summer, the country quickly becomes arid. Rivers and streams are few and insignificant, and the inhabitants of the towns and villages are obliged to rely for the most part upon wells or supplies of rain-water collected in catchment tanks. In certain parts of the country there are, however, perennial streams, and in some cases.these form extensive marshy tracts, affording breeding grounds for mosquitos during the greater part of the year. Irrigation is practised throughout the dry season in districts where the supply of water is sufficient from springs or surface wells.

The summer weather in the Jordan Valley can only be described as tropical. Along the coastal plain there is usually a sea breeze, but when this fails, the moist heat is often trying. The higher parts of the mountain ranges enjoy a succession of hot sunny days, tempered by cool breezes, with a greater fall in the temperature at night. The maritime plain, consisting for the most part of rich grain lands, orange groves and olive yards, varies in width from a narrow strip where the mountains approach the sea, to many miles where they recede.

The mountains of Judea and the Galileean hills, rising here and there to 3,000 feet, form the backbone of Palestine proper. They consist chiefly of barren limestone. To the eastward they descend in tumbled masses to the Jordan Valley, a unique and stupendous crack in the earth's crust, sinking to 1,200 feet below sea-level. On the far side the mountains of Moab divide the valley from the tablelands of Bashan and the Arabian desert.

The larger part of Palestine, especially the central and northern regions, Syria, and Cilicia are malarious. A fairly high percentage of the native population in some of the towns and villages has been found to be infected, and well known malaria-carrying species of Anopheles abound. The duration of the malaria season roughly corresponds to that of the dry period, from May to November. 
In early summer the Bedouins, with their flocks, descend to the plains in search of pasture and water. From their habits it has been assumed by some authoritie that the majority of these people are malaria-carriers, and in their wanderings assist in the spread of the disease, but I am not aware that this opinion is based upon any extensive investigations. It is possible that these people derive a certain protection from the fact that they are usually accompanied by numbers of the larger domestic: animals, horses, donkeys, camels and cattle. I have observed that frequently some of these are stabled under one end of the curiously shaped bivouac tents used by the Bedouins. These conditions appeared to be favourable for the feeding and sheltering of Anophelines.

Although I was unable to prove that Anopheline mosquitos prefer feeding upon animals rather than man in this part of the world, I have noticed, when searching camps, that they are usually to be found in larger numbers in tents pitched near horse or mule lines. In the towns and villages the number of large domestic animals would not be sufficient to supply food for the abundant Anopheles, and in these places, no doubt, they mostly subsist upon the blood of human beings.

One of the most abundant domestic mosquitos of the country is Anopheles bifurcatus. I have seen it breeding in countless thousands in the basement rainwater cisterns, which are to be found almost universally beneath and around private houses. As this stored water often represents the sole supply for the inhabitants during the summer, anti-malarial work is difficult, and opposition is sometimes met with.

In Jerusalem there are upwards of 4,000 basement cisterns, besides an extensive system of ancient drains and sewers, many of which have become blocked by subsidences. Some of these cisterns are of considerable size, having a rain-collecting platform as large as a tennis court, with a correspondingly large surface of water beneath. They are from 15 to 20 feet deep, and usually have only one opening about 2 feet square, so that a satisfactory examination is hardly possible. Even where a lid or cover has been made mosquito-proof, and a pump fitted to draw up the water, there is always an opening through which the rain enters. Mosquitos find their way in and out through this. Large surface wells protected by masonry are another frequent source of trouble. One of the most important medical problems with which the new Administration has to deal is the provision of an adequate piped water supply to all the towns, and the abolition of basement cisterns, surface wells and catchment tanks.

In Egypt, where the incidence of malaria is much less, the three chief Anopheline carriers of Palestine, viz. A. maculipennis var., A. bifurcatus and $A$. superpictus, are practically unknown. A. multicolor is there considered to be the principal carrier. It is common in the Canal zone, and especially abundant in the oases. It is in the last-named places that malaria is most prevalent. Here again the population is largely a nomadic one, tending to spread the disease from place to place. It is interesting to note that all the species of Anopheles so far found in Egypt occur also in Palestine, in spite of a wide strip of waterless desert separating the two countries. On the other hand, there are four or five species in Palestine which are absent from Egypt. 
Anopheles maculipennis, My., var.

This is generally distributed over Palestine, Syria and Cilicia, but although recorded from Egypt by earlier workers, has not been found there in recent years.

The adult has the wings less distinctly spotted, especially in the male, than the European form, ${ }^{*}$ some specimens being unspotted. The resting position on a vertical surface is rather flat, this being more noticeable in the male. Gorged females resting on a tent roof hang down in the usual Anopheline position.

Major S. R. Christophers discovered this faintly spotted form in Mesopotamia and wrote to me in regard to it, mentioning that the egg differs from that of the typical A. maculipennis (figured by Nuttall and Shipley in Journal of Hygiene, i, pl. ii, figs. 1 and 2) in that it has a frill of air cells all round the edge, instead of one pair of lateral floats. This observation I have been able to confirm in the eggs of Palestine specimens. The full-grown larva and the adult do not, however, appear to differ structurally from the type, and it remains to be seen whether the variety here referred to should be regarded as a distinct species.

The larvae are usually to be found in natural water both fresh and brackish. The adults have been found in very large numbers in tents and huts in camps, in various parts of the country, and often cause a heavy incidence of malaria. They will ometimes travel a considerable distance from the breeding-grounds, especially when emerging in large numbers. On 27th September 1919 I visited a camp at Toprak Kali, Cilicia, which was situated on a hill 500 feet high, and one and a half miles from the nearest water. In the earlier part of the year this site had been considered safe from a malaria point of view. The tents were, however, found to be heavily infested with both $A$. maculipennis var. and A. superpictus. Very similar observations were made on 1st October at a camp in the valley of the Ak river, near Marash, Northern Syria, from which large numbers of cases of malaria were being evacuated. In the first tent examined (square Indian pattern) there were over 300 Anopheles in one corner, while a patient lying beneath had 70 inside his mosquito net. These were nearly all $A$. maculipennis var., with a few $A$. superpictus; some of the former were noticed to be biting in the daytime. Although the river passed within a few hundred yards, very few larvae, or likely breeding-places, could be found. In marshy ground and rice fields at about one and a quarter miles distance, however. the larvae were in abundance.

Breeding commences in April and May, according to the season, in the marshy areas along the coastal belt of Palestine. In the Jordan Valley, at depressions below sea-level, it probably begins earlier. During the first part of May 1920, I collected large numbers of larvae and pupae in a shallow brackish marsh lying amongst the wandhills, east of Haifa, and near the mouth of the Kishon river. Larvae of several other species, viz. A. multicolor, A. hyrcanus, A. mauritianus, Culex univittatus and C. tipuliformis, were found at the same time. By the end of May larvae were much less numerous, the day temperature of the water in the marsh having then risen to $88-90^{\circ} \mathrm{F}$.

* The North European form has not been found in Palestine, but the two forms occur together in Macedonia. 
Adults of $A$. maculipennis var. were found in camps on the sands near the Kishon, and a few from time to time in camps above Haifa town at 300 feet; also in the lower western part of the town, at least one and a half miles from the nearest breeding place, as far as I could discover. Larvae were never found within the town limits, either in covered or uncovered collections of water.

At the end of April larvae began to appear in an area flooded by late rains, north of Acre town, in the neighbourhood of a battalion camp. This area soon became dry, but in the meantime large numbers of $A$. maculipennis var. had hatched out, and an outbreak of malaria occurred, lasting several months. The first primary case of benign tertian was reported on 28th May and of malignant tertian on 27th June.

The species occurs from 1,200 feet below sea-level to 2,300 feet above. My collection includes specimens from the following places :-

Palestine : Sarona (near Jaffa) ; Zummarin; Athlit; Haifa ; Acre; El Afule ; Jenin ; Tabgha (north of Tiberias), along the course of the Jordan from the Sea of Galilee to near the Dead Sea. Syria : Damascus; Homs; River Ak Valley (near Marash). Cilicia : Missis ; Jihan; Toprak Kali.

\section{Anopheles bifurcatus, $\mathrm{L}$.}

As mentioned previously, this is the most abundant domestic Anopheline mosquito of Palestine and Syria, breeding almost exclusively in basement rain-water cisterns and covered surface wells. I did not discover the larvae in any natural open water in Palestine, but at Beirut (Syria) larvae and pupae were taken from a small gently flowing stream containing much vegetation and over-grown with bushes. It appears to be essentially a cool-water species. The temperature of the water in basement cisterns in a coastal town, such as Haifa, varies between about $58^{\circ} \mathrm{F}$. in winter and $78^{\circ} \mathrm{F}$. in summer. During the spring and early summer, when breeding is most active, the water was found to remain at about $62^{\circ} \mathrm{F}$. Larvae may be found throughout the year in their favourite haunts, but feed up more slowly in winter than during the warmer months. The majority of larvae must pass their whole existence in semi-darkness, the sun's rays seldom penetrating to these deep cisterns.

Examinations were made at Haifa in November, before the autumn rains, when many of the cisterns were dry or contained very little water. In most cases they were clean, with very little, if any, debris upon the floor. In others, which had probably not been cleaned out for some years, the walls had become green, and there was a thicker floor deposit. Further investigations in January, after about six weeks of heavy rains, revealed the presence of very large numbers of adults. Collections were made of individuals resting on the walls, within reach of the opening. At first I was under the impression that they were all females, but while carrying out a series of fumigation experiments, it was found that in cases where all the mosquitos had not been killed by the fumes, most of the survivors were males. These wer: resting or flying about near the openings when the cisterns were examined. On several occasions in January I was bitten by females disturbed from cisterns.

Examinations were continued in April in parts of Haifa not previously visited. Larvae were found to be present in nearly every case, together with adults. Usually some larvae were obtained in the first bucket of water drawn. After that it was 
difficult to secure many more, even though in one case twenty buckets of water were examined in succession. When disturbed they evidently move away from the vicinity of the opening. As far as I could judge, from a number of observations made, the larvae of $A$. bifurcatus living in these situations are chiefly surface feeders, existing upon debris which may be washed in by the rains.

I successfully reared adults from the egg by keeping the larvae in a bowl of clean water and feeding them upon a diet of chopped flies. A few young larvae found on 18th November fed up slowly in the same way, living for about two months before pupating. The adults prefer cool and dark places in which to rest during the day, and were not found in any abundance in houses or tents.

Except for occasional individuals the species is absent from Egypt. Specimens were obtained in the following localities from sea-level to about 3,000 feet :-

Palestine : Jerusalem; Bethlehem; Jaffa ; Haifa ; Acre; Nazareth. Srria : Baalbek ; Zahle ; Beirut.

\section{Anopheles algeriensis, Theo.}

I think this must be the species referred to by previous workers in Palestine as A. fragilis, Theo., or A. aitkeni, James. It does not appear to be very general, and I have no records for Egypt or Cilicia.

One female was captured on 3rd December 1919 in a tent pitched in the marshes east of Acre; this had recently sucked blood. On 11th and 12th August 1920 it was found in numbers at Wadi Selhab, a marshy tract about three miles south of Jenin on the Nablus road and over twenty miles from the coast. The females were biting freely at sunset, and some fifty specimens were caught in half an hour. The only other mosquitos seen at the same time were $A$. hyrcanus and Culex pipiens (one).

It would appear to breed chiefly in the larger marshes, away from human habitations, like $A$. hyrcanus, and is therefore probably not a frequent carrier of malaria. It has been found in the marshy areas of the Auja valley, between Mulebbis and Jaffa.

A few specimens were bred from larvae found in a small marsh on the outskirts of Beirut, in September 1919.

Anopheles hyrcanus, Pall. (sinensis, Wied. ; pseudopictus, Grassi).

As mentioned above, this species breeds chiefly in the larger marshes and is to be found along the coastal belt of Palestine, at least as far north as Acre. It also occurs in suitable localities inland. I think there is no doubt that it is to be found in Svria and northwards, but I did not meet with it. I believe that up to the present it has not been found in Egypt.

The adults may be found nearly all the year round, but in larger numbers in winter and spring.

Palestine: Marshes in the Auja Valley, near Mulebbis; Athlit; the Kishon Plain, from Haifa to Acre; Wadi Selhab, near Jenin. 
Anopheles mauritianus, Grandpré.

This is one of the Anopheles which is to be found regularly in Palestine and Egypt. In the former country it breeds in much the same environment as $A$. hyrcanus, viz. the swamps of the Auja and Kishon rivers. I have not met with it inland, or in Syria. In Egypt it is found chiefly in the lake margins and swamps of the Delta.

The adults appear to be most common in the early part of the year.

\section{Anopheles superpictus, Grassi (palestinensis, Theo.; nursei, Theo.).}

Generally distributed over Palestine and Syria, and met with in Cilicia. The larvae are usually found in natural water, and prefer clear pools, near springs of fresh water.

The adults are no doubt responsible for a great deal of the prevailing malaria in country districts, as distinct from towns. My collection includes specimens from the following localities, from 1,100 feet below sea-level to about 3,000 feet above :-

Palestine: Sarona (near Jaffa) ; Ludd, Latron, Ram Alla (near Jerusalem); along the course of the river Auja from Rasel Ain to Mulebbis; Beisan; Tabgha; at many places along the Jordan from Beirut Yakub bridge, on the Upper Jordan, down to Ghoranyieh (near the Dead Sea). Syria : Ak river, near Marash; Zahle, Lebanon Mountains. Cilicia : Bozanti; Toprak Kali, Taurus Mountains.

\section{Anopheles culicifacies, Giles, var. sergenti, Theo.}

This mosquito was not discovered until the end of my stay, and I think it is probably often overlooked amongst numbers of the preceding. A few females were found in tents at Tabgha, on 15th August 1920. Previously a few specimens were bred from larvae found in pools along the Nazareth road, near Haifa.

\section{Anopheles multicolor, Camb. (chaudoyei, Theo.).}

This insect has been previously known to workers in Palestine as A. turkhudi, Liston. It is now found to be distinct from the Indian species.

The larvae are often found in large numbers in brackish marshes along the coastal plain of Palestine, in late autumn, spring and early summer. It is not, however, confined to the coast, and occurs in salty pools and streams in the Jordan Valley. As mentioned on a previous page, it is considered to be the chief malaria-carrier in Egypt, where it has a wide distribution.

\section{Anopheles pharoensis, Theo.}

Although abundant in some parts of Egypt, it is regarded as a doubtful carrier of malaria. In October 1919 I found it commonly at Kantara, on both sides of the Canal, and also in the northern suburbs of Cairo. It is very rare in Palestine, and I obtained only one female. This was found at Tabgha, north of Tiberias, on 15th August 1920. I have no records for Syria.

\section{Stegomyia fasciata, F.}

This is exclusively a domestic species, found in most parts of Egypt, Palestine and Syria, at least as far north and east as Aleppo. 
Larvae were found in water receptacles of all descriptions, including flower-vases in a sitting-room, fire-buckets containing clean water, and a disused boiler in a kitchen.

The adults are most troublesome in the hot season, and are suspected of being carriers of the organism causing "Aleppo sores" and "Jericho boils." Some of the Palestine specimens are very beautiful, having the dorsal surface of the abdomen almos s completely covered with silvery scales.

Palestine: Jaffa; Jerusalem; Haifa; Jenin; Tiberias. Srria: Beirut; Damascus ; Aleppo.

Ochlerotatus caspius, Pall. (dorsalis, Theo., nec Mg.)

A very abundant and widely distributed species in Egypt, but so far as my observations go, it is not so common in Palestine.

The larvae prefer brackish water.

A few adults were found at Haifa in June 1919.

The night of 31st March 1920 was spent at Jisr al Damie, Jordan Valley. During the evening we were attacked by clouds of mosquitos, but owing to an unfortunate accident to my supply of tubes, I was unable to bring back a large number of specimens. A few of this species were secured, together with $O$. detritus, Theobaldia annulata var., and Anopheles superpictus.

\section{Ochlerotatus mariae, Serg.}

One of the few mosquitos to be found breeding in sea-water. Large numbers of ova, larvae and pupae were found in pools above high water mark on the rocks at Athlit, Palestine, in August 1920. In June and July 1919 larvae were abundant in similar situations along the coast to the south-west of Beirut, Syria. The pools become very salt owing to evaporation, and the temperature of the water, by exposure to the sun, is usually well over $90^{\circ} \mathrm{F}$. for the greater part of the day.

The adults bite freely in the daytime, and cause much annoyance to people bathing from the shore.

Ochlerotatus detritus, Hal. (salinus, Fic.).

A very abundant and troublesome species in parts of Palestine during the wet season and spring.

The larvae are found chiefly in brackish water, near the coast, but $I$ also found them in large numbers in the Jordan valley at the end of March 1920, at 1,000 feet below sea-level.

Palestine : Zummarin; Haifa; Acre; Jisr el Damie, Jordan.

Culex pipiens, $\mathrm{L}$.

Abundant and widely distributed in Egypt, Palestine and Syria, and found as a rule near human dwellings. The species occurs from sea-level to 4,500 feet. 
The larvae differ in some respects from Western European and Mesopotamian specimens, and appear to represent a distinct race. No differences can, however, be discovered in the adults. Larvae collected in Jerusalem, Haifa and Baalbek (Syria), are very uniform in structure and size and show the following obvious differences from typical specimens :- Full-grown larva smaller, with distinctly shorter siphon; slightly smaller average number of pecten teeth ; antennae light, instead of dark. In one case larvae were found living in a well in which the waterlevel was 85 feet below the ground.

The adults exhibit a certain amount of variation in the abdominal banding, in some specimens the white bands being incomplete dorsally.

\section{[Culex fatigans, Wied.]}

Although this mosquito was recorded from Egypt by several of the earlier workers, it does not seem to be found there. An examination of the genitalia of all males. in the collection of the Egyptian Ministry of Agriculture has proved them to be C. pipiens. I have been unable to find the species in Palestine or Syria.

\section{Culex laticinctus, Edw.}

The larvae may sometimes be found in very large numbers in covered surface wells, tanks, and similar situations in Palestine.

The adults have been observed in quantities in tents in camps. In Egypt it is. found commonly at Alexandria.

PaLestine: Jerusalem; Wadi Hamish; Haifa. Syria : Baalbek.

\section{Culex univittatus, Theo.}

Distributed from Egypt to Syria, but never in any great abundance. The larvae live in marshes and stream pools, generally away from dwellings. One is liable to overlook them, as, when disturbed, they immediately leave the surface, returning for only a second or two at long intervals.

There still seems to be some confusion regarding the larval characteristics. My specimens disagree in almost every particular with the description and figure given in Bull. Ent. Res. x, p. 69, 1919; neither do they fit in with the synoptic table given in the same journal vol. iii, p. 381, Dec. 1912. I have handed some of my material to Mr. F. W. Edwards, who has kindly offered to go into the matter, and publish the results in a future paper.

Palestine: Wadi Hamish; Sarona; Haifa. Syria : Beirut.

\section{Culex tipuliformis, Theo.}

Found in similar situations to the preceding. It has not, so far as I am aware, been recorded from Egypt under this name, but there is a specimen from the Fayum. in the British Museum collection.

Palestine : El Afule; Acre; Haifa. Syria : Damascus. 
Culex hortensis, Fic.

Although I was on the look out for this species in Palestine, very few were found. Some females were taken at Haifa in May 1920. No doubt it is common enough in some parts of the country. At Damascus, in July 1919, larvae of this and of C. tipuliformis were dipped from the same pool. It appears to be absent from Egypt.

\section{Culex mimeticus, Noé.}

Not uncommon in suitable localities in Palestine, Syria and Cilicia, but absent from Egypt. The larvae have been found associated with those of $A$. superpictus.

Palestine: Wadi Hamish. Syria : Beirut. Cilicla : Bozanti.

\section{[Culex modestus, Fic.]}

This was not met with, but is likely to occur, since it has been found in Macedonia and Egypt.

\section{Theobaldia Iongiareolata, Macq.}

One of the commonest gnats in Egypt, Palestine and Syria. It is so universal that it is hardly necessary to give localities. This and the following species were found up to 4,500 feet in the Lebanon Mountains.

The larvae abound in water-barrels and other receptacles in gardens, surface wells, and covered and uncovered tanks and cisterns.

\section{Theobaldia annulata, Schrank.}

\section{Much less common than the last-named, and absent from Egypt.}

The strongly marked type form was taken at Ramleh, Palestine, and at Ain Sofar, Lebanon Mountains. In the Jordan Valley at 1,000 feet below sea-level, I found some specimens of a pale variety which agree with the Mesopotamian form, referred to in my paper on mosquitos of that region (Bull. Ent. Res. x, p. 325, 1920).

\section{Theobaldia morsitans, Theo.}

At the end of April 1920 some larvae were found in a pool at the bottom of a small quarry at Haifa. The species was not met with elsewhere.

\section{[Taeniorhynchus richiardii, Fic.]}

This species has been found in Palestine, at Jell Zahmûl, Huleh, by Dr. J. Cropper, but was not met with by the author.

\section{Uranotaenia unguiculata, Edw.}

Widely distributed in Egypt, and found in parts of Palestine. The larvae as a rule are only to be found in the larger swamps.

My thanks are again due to Dr. Guy A. K. Marshall, Director of the Imperial Bureau of Entomology, and Mr. F. W. Edwards, of the British Museum, for assistance in the identification and synonymy of certain of the species and forms mentioned above. Also to Mr. G. Storey, of the Egyptian Ministry of Agriculture, for information as to the distribution of mosquitos in Egypt. 